\title{
Tris(2-methoxyphenyl)phosphine as a Highly Active Ligand for the Synthesis of Biaryls by Suzuki Coupling Reaction
}

\author{
Pill-Seong Kang, ${ }^{\dagger}$ Sung Bo Ko, Jang Myoun Ko, and Jeong Ho Park \\ Division of Applied Chemistry and Biotechnologv. Hambat National Cniversin, Daejeon 305-719, Korea \\ ${ }^{*}$ E-mail: jhparkahanbatackr \\ Medigen Inc. Daejeon $305-811$. Korea \\ Received July 31, 2009, Accepted September 30, 2009
}

\begin{abstract}
A Pd(OAc) $)_{2} /(O-\mathrm{MeOPh})_{3} \mathrm{P}$ system has been developed for the catalytic suzuki coupling of aryl bromides with arylboronic acids. Our catalyst system covers a broad spectrum of commonly available arylboronic acids and aryl bromides to provide biaryls in very good yields. The catalyst sy stem works very well in the synthesis of sterically hindered biaryls.
\end{abstract}

Key Words: Tris(2-methoxỵphenỵl)phosphine. Suzuki coupling reaction

\section{Intoduction}

The palladium catalyzed Suzuki cross-coupling of aryl halides with arylboronic acids results in biaryl compounds (Scheme 1) and has emerged as an extremely powerful tool in organic synthesis. 'The biaryls are one of the important classes of organic compounds because various types of compounds such as natural products. electronic materials. liquid crystals and phanmaceuticals include the biary units.

Therefore intensive studies in regard to the biaryl syththesis have been carried out ${ }^{2}$ and several kinds of phospline ligands

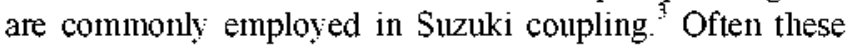
ligands are sensitive to air oxidation and need several steps for the synthesis. We now wish to report the results of a simple and efficient combination of $\mathrm{Pd}(\mathrm{OAc})_{2} /(\mathrm{O}-\mathrm{MeOPh})_{3} \mathrm{P}$ as a catalytic system in Suzuki coupling reactions.

\section{Results and Discussion}

Tris(2-methoxyphenyl)phosphine ${ }^{4}$ (Fig. 1, L3) is readily available from anisole and very stable to air oxidation (see experimental section for the preparation of the ligand $\mathbf{L 3}$ ). Also the ligand is expected to satisfy the demands of bulkiness

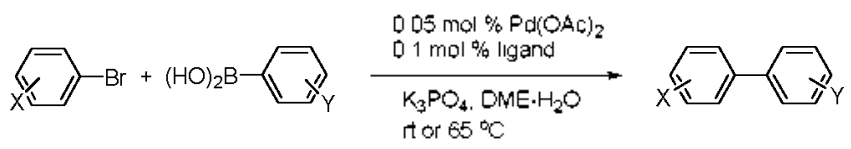

Scheme 1. General synthesis of biaryls through Suzuki coupling reaction.

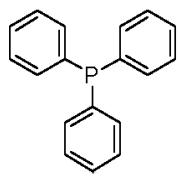

$\mathbf{L} 1=\mathrm{PPh}_{3}$

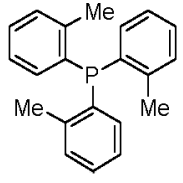

L2 $=\left(0-t_{0}|y|\right)_{3} P$

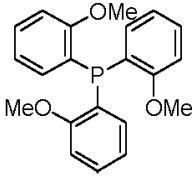

$\mathbf{L} 3=(0 \cdot \mathrm{MeOPh})_{3} \mathrm{P}$
Figure 1. Structure of organophosphine ligands. and basicity which are often required for the cataly tic activity in Suzuki coupling. In this paper we described the ligand effect of $(o-\mathrm{MeOPh})_{3} \mathrm{P}$ in several Suzuki coupling reactions between aryl halides and arylboronic acids. $\mathbf{L 3}$ has been shown to be superior to triphenỵlphosphine in many palladium-catalyzzed coupling reactions.

Preliminary Suzuki coupling reactions between ortho-substituted aryl halides and aryl boronic acids using different ligands such as $\mathrm{PPl}_{3}$. $(o \text {-tolyl })_{3} \mathrm{P}$ and $(o-\mathrm{MeOPh})_{3} \mathrm{P}$ were carried out with usual condition for Suzuki coupling. i.e. $\mathrm{Pd}(\mathrm{OAc})_{2}$ as a palladium source and $\mathrm{K}_{3} \mathrm{PO}_{4}$ as base in $\mathrm{DME} / \mathrm{H}_{2} \mathrm{O}(4: 1)$ at $65^{\circ} \mathrm{C}$ (Table 1). Ortho-substituted anyl halides with methyl or methoxy group gave both electron donating effect and steric hindrance. We observed that the ligand $\mathbf{L 3}$ dramatically improved the isolation yield from $64 \sim 69 \%$ to $96 \%$ with orthomethyl aryl halides compared to other ligands [L1 and L2] (Table 1. entrie 2, 3 and 4)

The steric factor of the coupling site on aryl boronic acid did give a great influence on the coupling yield. The introduction of isopropyl group on the ortho position of aryl boronic acid reduced the coupling yield to $54-69 \%$ at the coupling reaction using $\mathbf{L} 1$ or $\mathbf{L} 2$ (Table 1 . entrie 10 and 11 ). In contrast, $\mathbf{L 3}$ resulted in 2'-isopropyl-2-methosybiphenyl (3) in very high yield regardless of the presence of isopropyl group on the ortho position of arylboronic acid (Table 1. entry 12). Therefore. ( $o-\mathrm{MeOPh})_{3} \mathrm{P}$ proved to be excellent ligand for the coupling reaction between sterically hindered arylboronic acids and aryl bromides.

Encouraged by these results. we carried out the construction of polyaryl frameworks from 2,6-dibrono-4-methylanisole and arylboronic acids with our cataly st sy stem. The corresponding polyaryls $\downarrow$ and 5 were obtained with satisfactory yield (Scheme 2).

Even though excellent results have been achieved between the coupling of wide range of aryl bromides and boronic acids. coupling reactions between ortho-substituted aryl bromides and di-ortho-substituted arylboronic acids are challenging reactions because of forming highly hindered biaryls. We examined the tolerance of ortho-substitution in both the aryl 
Table 1. Ligand effect on Suzuki coupling reaction. ${ }^{\sigma}$

entry

"The Suzuki coupling reaction was carried out on the condition $\left(0.05\right.$ molo, $\mathrm{Pd}(\mathrm{OAC})_{2}, 0.1$ mol ${ }^{0}$ ligand. 3.5 equiv $\mathrm{K}_{3} \mathrm{PO}$ in $\mathrm{DME}-\mathrm{H}_{2} \mathrm{O}$ at $\left.65^{\circ} \mathrm{C}\right)$.<smiles>COc1cc(Br)cc([N+](=O)[O-])c1</smiles><smiles>COc1ccc2ccccc2c1</smiles><smiles>COc1cc(Br)cc(Br)c1</smiles><smiles>Oc1ccc(-c2ccccc2)cc1</smiles>

Scheme 2. Synthesis of polyaryls 4 and 5 .

halides and the ary lboronic acids. Unfortunately, our standard reaction condition was not suitable for the synthesis of more sterically hindered biaryls when the boronic acid has di-orthosubstitution group. For example. coupling reaction between 2-bromoanisole and 2.4.6-trimethy lboronic acid was carried out to give 2'-methoxy-2.4.6-trimethylbiphenyl (6) (Table 2. entry 1 ) in only $36 \%$ yield. To improve yield the base $\mathrm{K}_{3} \mathrm{PO}_{4}$ was replaced by $\mathrm{Ba}(\mathrm{OH})$. and the isolation yield moderately improved to $65 \%$ (Table 2 . entry 2 ).

Striking ligand effect was observed when substitution on aryl boronic acid and aryl halide was switched each other.

Table 2. Screening of base effect in sterically hindered coupling reaction with 2-bromoanisole and 2,4,6-trinethylboronic acid

$\begin{array}{ccccc} & & & \\ \text { baselsolvent reflux }\end{array}$

With ( $\sigma$-tolyl) $)_{3} \mathrm{P}$. Suzuki coupling reaction of 2.4,6-trimethylbromobenzene and 2-methoxyphenylboronic acid gave a trace amount of biaryl 6 even at the elevated temperature $(90$ ${ }^{\circ} \mathrm{C}$ ). On the contrary. $(o-\mathrm{MeOPh})_{s} \mathrm{P}$ provided the desired product in $90 \%$ yield at mild condition (Table 3 . entry 2 ).

Finally, the effect of electronic variation on aryl halides was tested by using phenlyboronic acid. Regardless of the electron-donating or electron-withdrawing substitution, Suzuki coupling reaction progressed smootluy and resulted in desired product in very high yield (Table 4).

Table 3. Ligand effect on sterically hindered substrate

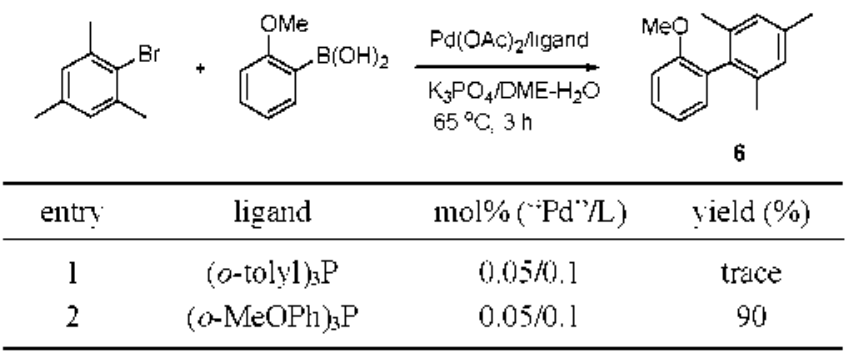

The Suzuki coupling reaction was carried out on the condition $(0.05$ $\mathrm{mol}^{0}{ }_{0} \mathrm{Pd}\left(\mathrm{OAC}_{2}, 0.1 \mathrm{~mol}^{0}{ }_{0}\right.$ ligand. 3.5 eq. $\mathrm{K}_{3} \mathrm{PO}_{4}$ in DME- $\mathrm{H}_{2} \mathrm{O}$ at $\left.65^{\circ} \mathrm{C}\right)$. 
Table 4. Synthesis of biaryls with electronic variations on arylbromides and ary lboronic acids. ${ }^{a}$

entry aryl halide boronic acid

${ }^{a}$ The Suzuki coupling reaction was carried out on the condition $(0.05$

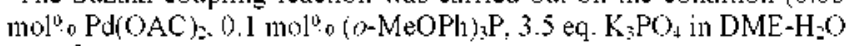
at $\left.65^{\circ} \mathrm{C}\right)$.

\section{Conclusions}

In summary, a general and highly efficient sythesis of biaryls based on $\mathrm{Pd}(\mathrm{OAc})_{2} /(\mathrm{O}-\mathrm{MeOPh})_{3} \mathrm{P}$ system has been developed. The use of $(o-\mathrm{MeOPh})_{3} \mathrm{P}$, which is very stable to air oxidation and easy to prepare. represents an alternative to existing cataly tic systems based on the use of phosphine ligands. Further investigation will be carried out to apply the use of $(o-\mathrm{MeOPh})_{3} \mathrm{P}$ ligand toward the Suzuki reaction of aryl chloride and more hindered substrates as well as Pd-catalyzed amination reactions.

\section{Experimental Section}

Preparation of tris(2-methoxyphenyl)phosphine (L3). ${ }^{6} n$-BuLi $(210 \mathrm{~mL}$ of $1.6 \mathrm{M}$ in hexane or $130 \mathrm{~mL}$ of $2.5 \mathrm{M}$ in hexane. $0.32 \mathrm{~mol}$ ) was placed into $1 \mathrm{~L}$ three neck round bottom flask equipped with dropping funnel under $\mathrm{N}_{2}$ atmosphere. Tetramethy lethylene diamine (TMEDA, $48.3 \mathrm{~mL}, 0.32 \mathrm{~mol}$ ) was dropwise added to the reaction flask at room temperature and then anisole $(43.5 \mathrm{~mL} .0 .4 \mathrm{~mol}$ ) was slowly added to the flask. Exothermic reaction took place and the reaction mixture was stirred for $30 \mathrm{~min}$ at $45 \sim 50{ }^{\circ} \mathrm{C}$. The reaction mixture was cooled down to $-70^{\circ} \mathrm{C}$ and then dry THF (100 mL) was added. The flash distilled $\mathrm{PCl}_{3}(8.8 \mathrm{~mL} .0 .1 \mathrm{~mol})$ was slowly added to the nuixture during maintaining reaction temperature at $-70^{\circ} \mathrm{C}$ for $10 \mathrm{~min}$. The cooling bath was removed and the temperature was raised to $-10^{\circ} \mathrm{C}$. The reaction was quenched by adding $2 \mathrm{M} \mathrm{HCl}(500 \mathrm{~mL})$ to the reaction nixture. The white solid appeared and the solution was filtered to separate the white solid (22 g, 63\%). No recry stalization was necessary: ' $\mathrm{H} N \mathrm{NR}$ $\left(\mathrm{CDCl}_{2}, 300 \mathrm{MHz}\right): 7.32$ (t. $\left.3 \mathrm{H}\right), 6.83(\mathrm{~m}, 6 \mathrm{H}), 6.69(\mathrm{~m}, 3 \mathrm{H})$, $3.73(\mathrm{~s}, 9 \mathrm{H})$ : Mass $[\mathrm{M}+\mathrm{H}]: 353.1$.

General Procedure for Suzuki Coupling Reactions.

Preparation of $o$-phenyanisol (2). A misture of $o$-bromoanisole $(1.0 \mathrm{~g}, 5.35 \mathrm{~nm}$ ol) . phenylboronic acid $(0.72 \mathrm{~g}, 5.88$ mmol). $\mathrm{Pd}(\mathrm{OAc})_{2}(60 \mathrm{mg} .0 .27 \mathrm{mmol} .0 .05 \mathrm{~mol} \%$ ). (o-MeOPh) (100 mg. 0.54 nimol, $0.1 \mathrm{~mol} \%$ ), and $\mathrm{K}_{5} \mathrm{PO}_{4}(33.97 \mathrm{~g}, 18.7$ mmol $)$ in DME- $\mathrm{H}_{2} \mathrm{O}(10 \mathrm{~mL}, 4: 1)$ was heated to $60 \sim 65^{\circ} \mathrm{C}$ and stirred for $4 \mathrm{~h}$. The reaction was monitored by TLC. When the reaction was complete. it was diluted with ether. The aqueous layer was extracted two times with ether, the combined organic extracts were applied directly to celite to remove the palladium cataly st and the eluent was dried $\left(\mathrm{Na}_{2} \mathrm{SO}_{4}\right)$. After evaporation of the organic layer, the resulting residue was purified by flash column cluromatography (silica gel, hexanes) to give the product as colorless oil (0.98 g. $5.32 \mathrm{mmol})$ in $99 \%$ yield.

2-Methylbiphenyl (1): ${ }^{1} \mathrm{H}$ NMR $\left(\mathrm{CDCl}_{3} .400 \mathrm{MHz}\right): \delta 2.26$ (s. $3 \mathrm{H}), 7.22(\mathrm{~m}, 2 \mathrm{H}) .7 .32(\mathrm{~m}, 3 \mathrm{H}) .7 .37(\mathrm{~m}, 2 \mathrm{H}) .7 .6 \mathrm{l}(\mathrm{d} . J=$ 1.6 Hz, 2H)

2-Methoxybiphenyl (2): ${ }^{\mathrm{H}} \mathrm{HMR}\left(\mathrm{CDCl}_{\mathbf{3}} 400 \mathrm{MHz}\right)$ : $\mathrm{o} 3.80$ (s. $3 \mathrm{H}), 6.99(\mathrm{~m}, 2 \mathrm{H}) .7 .30(\mathrm{~m}, 3 \mathrm{H}) .7 .40(\mathrm{dd}, J=1.6 \mathrm{~Hz}, 2 \mathrm{H})$. $7.52($ d. $J=1.6 \mathrm{~Hz}, 2 \mathrm{H})$.

2'-Isopropyl-2-methoxybiphenyl (3): ${ }^{1} \mathrm{H} \mathrm{NMR}\left(\mathrm{CDCl}_{3} 400\right.$ $\mathrm{MHz}$ ): ô 1.04 (d. $J=6.8 \mathrm{~Hz} .3 \mathrm{H}) .1 .19$ (d. $J=6.8 \mathrm{~Hz}, 3 \mathrm{H}) .2 .77$ (m. IH). 3.74 (s. 3H). 6.97 (q. 2H). $7.14(\mathrm{~m} .3 \mathrm{H}) .7 .35$ (m. 3H).

2"-Methoxy-5"-methyl-[1,4';1',1";3",1 "m:4" , 1"']quinquephenyl (5): ' $\mathrm{H} \mathrm{NMR}\left(\mathrm{CDCl}_{3} .400 \mathrm{MHz}\right): \delta 2.42$ (s, 3H), $3.2+$ (s, 3H). 7.18 (s. 2H). 7.36 (t. 2H). 7.45 (t. 2H). 7.71 (m. 10H).

2'-Methox y-2,4,6-trimethylbiphenyl (6): ${ }^{\mathrm{H}} \mathrm{H} \mathrm{NMR}\left(\mathrm{CDCl}_{3}\right.$. $400 \mathrm{MHz}$ ): $\dot{\delta} 1.98$ (s. $6 \mathrm{H}$ ) 2.33 (d. $J=6.8 \mathrm{~Hz}, 3 \mathrm{H}), 3.74$ (s. $3 \mathrm{H}) .6 .94$ (q. $2 \mathrm{H}), 7.02$ (n. $3 \mathrm{H}) .7 .35$ (m, lH).

5-Fluoro-2-methoxybiphenyl (7): ${ }^{\mathrm{H}} \mathrm{H} \mathrm{NMR}\left(\mathrm{CDCl}_{\mathbf{s}} .400\right.$ $\mathrm{MHz}$ ): $\delta 3.77$ (s. $3 \mathrm{H}), 6.89$ (q. $\mathrm{lH}$ ). 6.97 (t. lH). 7.04 (dd. IH). 7.35 (t. $1 \mathrm{H}) .7 .41$ (t. $2 \mathrm{H}) .7 .51$ (d. $2 \mathrm{H})$.

5-Benzyloxy-2-methoxybjphenyl (8): ${ }^{\mathrm{l}} \mathrm{H}$ NMR ( $\mathrm{CDCl}_{2}, 400$ $\mathrm{MHz}): \delta 3.79(\mathrm{~s} .3 \mathrm{H}), 4.95(\mathrm{~s}, 2 \mathrm{H}) .6 .81(\mathrm{~d} .1 \mathrm{H}) .6 .92$ (t. $2 \mathrm{H})$, $7.35(\mathrm{~m} .8 \mathrm{H}) .7 .57$ (d. $2 \mathrm{H})$

Aclonowledgments. This work was financially supported by the World Class University Program from Ministry of Education. Science and Technology, Korea.

\section{References}

I. (a) Miyaura, N.; Yamada, K.; Suzuki, A. Tetritedron Lett. 1979. 20, 3437. (b) Mivaura, N.; Suzuki, A. Chem. Rev. 1995, 95 , 2457. (c) Suzuki, A. J. Organometal. Chem. 1999, 576, 147. (d) Molander, G. A.; Ellis, N. Acc. Chent. Res. 2007, 40, 275.

2. (a) Thimmaiah, M.: Fang. S. Tetrahedron 2007,63,6879. (b) Nishimura, M.; Ueda, M.; Miyalia, N. Tenahedron 2002, 58 , 5779. (c) Shi, J.C.; Yang, P.-Y.; Tong, Q.; Wu, Y.; Peng, Y. J. Mol. Cat. 2006, 259,7.

3. (a) Kevin, H. S.: Rebecca, S. B. Org. Lett. 2001, 3, 2757. (b) 
Littke, A. F.; Dai, C.: Fu, G. C. J. Am. Chem. Soc. 2000, 122, 4020. (c) Hoshi, T.; Nakazawa, T.: Saitoh, I.: Mori, A.: Suzuki, T.: Sakai, T.: Hagiwara, H. Org. Lett. 2008, 10, 2063. (d) Billingsley, K.: Buchwald, S. L. J. An. Chen. Soc: 2007, 129, 3358. (e) Moore, L. R.: Westem, E. C.: Craciun, R: Spruell, I. M.: Dixon, D. A.; O'Halloran, K. P.: Shaughnessy, K. H. Organometallics 2008, 27, 576

4. For some examples of the use of the ligand, see: (a) Hagio, $\mathrm{H}$; Sugiura, M.: Kobavashi, S. Org. Letr. 2006, 8, 375. (b) Okamoto,
K.; Akiyama, R.: Kobayashi, S. Org. Lett. 2004, 6, 1987. (c) Cai, C.; Shung, I. Y. L.; McWilliams, I. C.; Sun, Y.: Schultz, C. S.: Paluck, M. Organic Process Res. Dev. 2007, 11, 328.

5. (a) Singh, R.; Viciu, M. S.; Kramareva, N.; Navarro, O; Nolan, S. P. Org. Lett. 2005, 7, 1829 (b) Baillie, C.; Zhang. L.; Xiao, J. J. Org. Chemt. 2004, 69,7779.

6. For the preparation of the ligand $\mathbf{L 3}$, see: Brandsma, L; Verkrujisse, H. D. Synth. Commm. 1990, 20, 2273. 